\title{
The Influence of Leadership, Performance Appraisal System, Work Motivation on Job Satisfaction and Employee Performance of PT PDSI
}

\author{
Agus Susanto ${ }^{1}$, Masydzulhak Djamil ${ }^{2}$, Ahmad Badawi Saluy $^{3}$ \\ \{agus_ebon@yahoo.com¹, masydk@gmail.com², ahmad.badawi@mercubuana.ac.id²\} \\ Mercu Buana University, Jakarta, Indonesia ${ }^{12}$
}

\begin{abstract}
This study aims to determine, describe, measure and analyze the influence of Leadership, Performance Appraisal System, Work Motivation on Job Satisfaction and Employee Performance of PT PDSI. The subjects of this study are employees of PT PDSI representing all sections. The data obtained were analyzed using Multiple Linear Regression using SPSS version 24. Where the results of the study showed that there was a significant influence of Leadership and Motivation variables on employee job satisfaction while the Performance Evaluation System variable did not affect employee job satisfaction. Furthermore, for the variable of leadership has a significant influence on employee performance, while the Performance Appraisal System and Motivation has no effect on employee performance. Job satisfaction has a significant effect on employee performance. The better job satisfaction obtained by employees; the employee's performance will also improve. Job satisfaction mediates the relationship between work motivation and employee performance.
\end{abstract}

Keywords: Leadership, Performance Evaluation System, Work Motivation, Job Satisfaction, Employee Performance

\section{Introduction}

The era of disruption that is happening right now has a real impact on the business environment. The uncertainty of the global economy can indirectly change the global business order which information technology plays an important role. Speed of service, productivity, the power of innovation, collaboration and adaptive to change are the keys to winning increasingly fierce business competition. Externalities in this dynamic business environment, of course, must be balanced with steady transformation in the company's internal business environment. One way to maintain company performance is to strengthen human resource management.

Based on the discussion of some of the variables mentioned above relating to job satisfaction and employee performance, the researchers tried to conduct research studies on employees. PT PDSI is a subsidiary of PT. Pertamina (Persero) which is engaged in providing drilling and work over services for oil, gas and geothermal wells. PT PDSI manages 43 units of onshore rig, non-rig services and other services such as integrated project management), top drive systems, coring, fishing, H2S monitoring, water pumps, aerated drilling, directional drilling and Bonded Logistics Center. 
PT PDSI was chosen as the object of research based on the transformation program carried out by PT PDSI as a program of response to the occurrence of global economic uncertainty marked by the occurrence of the world oil price crisis in 2015. Improving performance management is carried out across all functions, primarily prioritizing improvements in the source sector human resources. Performance Management at PT PDSI was made with the aim of increasing the involvement and commitment of workers towards the assignment in order to achieve the stated goals and targets of the company. High employee performance is expected to be a way for organizations to achieve high organizational performance as well. Performance can be seen from two sides, namely, individual performance and organizational performance. Individual performance is the work of a person or employee, while organizational performance is the entire work produced by the organization or company. Individual and company performance are interrelated.

Pre research conducted at PT. PDSI is carried out by distributing questionnaires containing questions related to variables that affect job satisfaction and employee performance at 40 employees of PT. PDSI. The results of the pre study conducted are as follows:

Based on the inconsistencies of the pre-research results, the researcher is interested in reexamining some of the variables above in their effects on employee performance. The difference between this research and other studies is that this study looks at employee satisfaction and employee performance in terms of the influence of the scope of the company, which is the leadership factor and from the internal scope of the employees, namely the work motivation of employees.

In addition, the employee performance appraisal system is also investigated as a bridge in measuring standardized employee intrinsic and extrinsic factors. Gibson et al [1] describe these characteristics can be explained as follows: (1) intelligence, , (2) personality, research provides data on the personality of leaders having the ability to change, authenticity, integrity personal, self-confidence in the effectiveness of leadership, (3) physical characteristics, shows there is a relationship between leadership effectiveness and physical characteristics such as age, height, gender, weight, with different research results, (4) supervision ability, shows there are rank positive relationships between abilities and organizational hierarchy. Also identified two forms of leader behaviour, namely: The Job Cantered Leadership; Leadership oriented to subordinates (The Employee Cantered)

\subsection{Performance Rating System}

Performance appraisal system refers to the theory of Three Social Motives (Trichotomy of needs) put forward by Mc Cleland, a psychologist from the United States. McClelland pioneered work motivation thinking, developed achievement-based theories and motivational models, and was promoted in improving employee assessment methods, as well as competency-based advocacy assessments and tests. The three motives are: Achievement Motive (nAch): Motive for achievement, Affiliation Motive (nAff): Motive for friendship, Power Motive (nPow): Motive for power (Robbins).

Keeping and Levy [2] state that there are four main components of implementing a performance appraisal system that can later be evaluated whether the system used is effective or failed, namely: (1) the appraisal process, namely, guidance on policies and procedures used to implement and manage the performance appraisal process, (2) the appraisal interview i.e., regarding formal meetings held between appraisers and valuers as a process for delivering feedback to priceless, discussing performance appraisal results, defining and discussing performance goals that need to be achieved in the future, $(3)$ the appraisal 
outcome that is, related to training opportunities, career development, salary increases, and performance ratings and (4) Fairness that is, relating to openness in which there are aspects of accuracy, transparency, timely and accountable.

McShane and Von Glinow [3] state that job satisfaction is an individual evaluation of the task and work context. Job satisfaction is related to judgments about work characteristics, work environment, and emotional experience at work. Employees are satisfied with their performance appraisal system when there is trust from supervisors and when supervisors support feedback from assessment results, especially in the areas of skills development, pay for performance, etc. Career progress occurs during the assessment session, and subordinates feel that they are given enough time to express their perspectives, have the opportunity to influence the results and sufficient explanation of their rating ratings according to Whiting, et.al [4].

\subsection{Motivation}

Herzberg et al. [5] developed a motivational model for job satisfaction, in his research finding that work related factors can be divided into two categories, Hygiene factors and motivation factors. This discovery is known as the Two Factor Motivation Theory. Hygiene factors alone cannot cause satisfaction but they can change dissatisfaction into no dissatisfaction or short-term motivation, whereas motivation factors have a long-term effect because they increase positive feelings towards work and turn dissatisfaction into satisfaction. In the absence of hygiene factors (ie work conditions, quality and level of supervision, company policies and administration, interpersonal relations, job security, and salaries) the opportunities for employees to get dissatisfaction increase.

According to Robbins \& Judge [6], motivation is a process of how a person can achieve his goals with the direction, strength and perseverance he has. Whereas for Kreitner and Kinicki [7], motivation is a process of human psychology in carrying out a behavior that has a specific purpose. Gibson et al. [1], argue that motivation can be defined as an effort made by individuals to initiate and direct behavior. Robbins and Judge [6], [8] argues that in motivation there are three elements in the definition of motivation, namely strength, direction, and perseverance. Strength illustrates how someone wants to work hard to achieve goals. Directives describe how a person uses his strength in the direction that is able to benefit himself, or the organization. Finally, perseverance is about how a person is able to maintain his efforts.

According to Mathis and Jackson [9] the desire of someone who causes someone to take an action is called motivation. Motivation causes people to act to achieve their goals. Understanding of motivation is different because different theories have developed different points of view. Understanding motivation is important because employee involvement can affect performance and retention. Fostering motivation can improve performance and reduce employee turnover. Motivation can be divided into two elements, namely external and internal elements. The inner element is the influence from within a person, such as one's desires and abilities in carrying out their duties. The external element is the influence of the environment in which a person engages in his activities. These elements will encourage the performance of employees to be able to work hard by giving all their energy and ability to realize organizational goals according to Hasibuan [10].

Thus, employee work motivation must be high because it will be reflected in their performance because with low work motivation, they will make smaller efforts to increase according to Raziq \& Maulabakhsh [11]. Beside that work motivation partially has a positive and significant effect to employee's performance according to Saluy, A. B., \& Treshia, Y 
[12]. Indicators related to work motivation according to Djamil and Zaenudin [13] are as follows: Physiological needs, Safety and security needs, Social needs, The need for appreciation, Self-actualization.

\subsection{Job Satisfaction}

According to Vroom [14] Job satisfaction is the emotional orientation employees have towards the roles they perform in the workplace. Job Satisfaction is an important component for employee motivation and drive for better performance. Many experts have defined job satisfaction over the years, for example Hoppok \& Spielgler [15] defines job satisfaction as a set of integrated psychological, physiological and environmental conditions that encourage employees to acknowledge that they are satisfied or happy with their work. Furthermore, the role of employees in the workplace becomes an emphasis, because there are influences of various elements on employees in the organization. According to Luthans [16] job satisfaction is influenced by several factors including: work itself, satisfaction with compensation, career promotion opportunities, satisfaction with supervision, satisfaction with personal relationships,

\subsection{Employee Performance}

Performance is basically about what is done and what is not done by employees. Employee performance will be able to give an idea of how an employee contributes to the organization. Performance improvement for individuals and groups must be the center of attention of the organization in an effort to achieve optimal performance according to Mathis and Jackson [9]. Mathis and Jackson [9] mentioned that to measure and identify employee performance there are several criteria. Each job has varying criteria, but there are the most common criteria in measuring performance, including: Output Quantity, Output quality, Timeliness of output, Work presence, Work efficiency, Effectiveness of work result.

Referring to the results of pre-research on employees of PT. PDSI shows that the highest factors that are considered by employees to affect employee performance are: a) Job satisfaction, b) Pride in working at PDSI (Motivation), c) Leadership, and d) Performance Appraisal System. On the basis of the results of pre-research that has been done, this study focuses on discussing the variables of job satisfaction, leadership, performance appraisal systems and work motivation as variables that affect employee performance. Another result that supports the influence between motivation and performance variables is research from Djamil and Zaenudin [13] and Budiman et al [17] which also proves that motivation has a significant positive effect on employee performance. However, it is different from the research results of Hanifah [18] which state that work motivation does not have a significant effect on employee performance. Regarding the leadership variable, the results of the research by Azzuhri [19] which states that leadership style has no effect on job satisfaction. Meanwhile, the research results Deneire et al. [20]; Hidayat [21]; Mukti et al. [22] show that performance appraisal is a factor that affects job satisfaction.

Based on the inconsistency of the research results above, the researcher is interested in re-examining some of the above variables in their effect on employee performance. The difference between this study and other research is that this study looks at employee satisfaction and employee performance from the perspective of the influence from the company environment, namely the leadership factor and from the internal scope of the employee, namely employee motivation In addition, the employee performance appraisal system was also studied as a bridge in measuring standardized intrinsic and extrinsic factors 
of employees. This research is also locus research conducted at PT. PDSI, which is as short as researchers' knowledge, has never been done

\section{Research Method}

Based on the characteristics of the problem under study, the type of research used in this study is causality research. This research is directed to describe the existence of a causal relationship between several situations that are described in variables, and on that basis then a general conclusion will be drawn. The type of data and analysis in this research is quantitative. Qualitative data that are collected are available on a measurement scale using answers in the form of scores. Data analysis was performed with multiple linear regression using SPSS software program version 24.00, to analyze whether there is an influence between the independent variables on the dependent variable and also the effect of the intervening variable. But before testing with multiple regression will be done first testing the validity, reliability and classic assumptions.

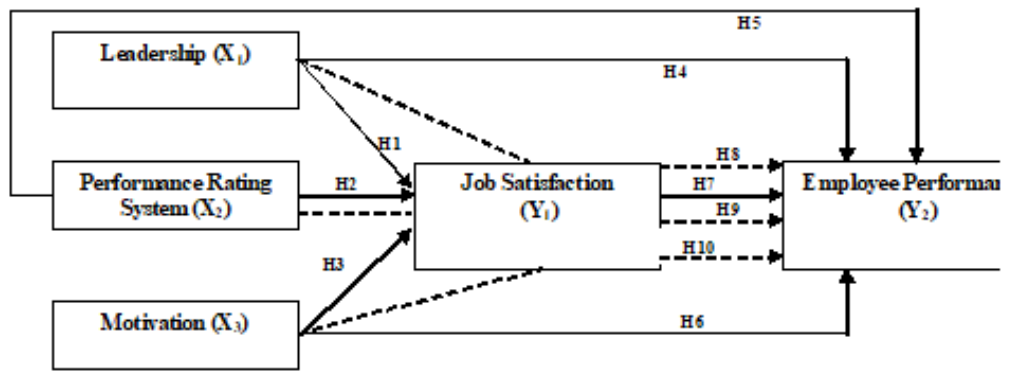

In this study, five variables will be presented, namely the leadership variable (X1), the Performance Evaluation System variable (X2) and the Work Motivation variable (X3) as independent variables. Job Satisfaction variable (Y1) and performance variable (Y2) as the dependent variable. In this study, Job Satisfaction variable (Y1) as a mediator of the independent variable on the dependent variable (Y2) performance. The data source used in this study uses primary and secondary data sources. Primary data sources were collected directly by researchers in the field by distributing questionnaires and interviews. Data collection techniques using a questionnaire intended to obtain the data needed to obtain information by giving a list of questions to respondents. With the hope that respondents will provide responses to questions in the questionnaire. In the measurement, each respondent was asked for his opinion on the question by using a Likert scale.

Data analysis was performed with multiple linear regression using SPSS software program version 24.00 , to analyze whether there is an influence between the independent variables on the dependent variable and also the effect of the intervening variable. But before testing with multiple regression will be done first testing the validity, reliability and classic assumptions. The population in this study were all employees at PT. Pertamina Drilling Services Indonesia. looking the number of employees at PT. Pertamina Drilling Services Indonesia, which numbered about 320 people, so in this study the sampling technique used was a probability sampling. The method or sampling technique above is done by simple random sampling (simple random sampling) where the researcher distributes questionnaires directly to the respondents chosen to be the sample, this is done by the researcher because the consideration of the sample is homogeneous or there are no significant differences in the 
characters of each element or population element. To determine the size of the sample size to be studied from all employees used the Slovin formula

\section{Results and Discussion}

The instrument used in this study was a questionnaire. Of the questionnaires distributed a total of 178 questionnaires, returning 100 questionnaires. A total of 36 questionnaires could not be processed because the filling was incomplete, so only 64 questionnaires were fulfilled for further processing. All respondents in this study have filled out all the questionnaire questions. Based on gender, the research respondents consisted of $47(73.4 \%)$ male respondents and $17(26.6 \%)$ female respondents, so the majority of respondents were male behavior. The results of the description of the length of work there were no respondents who worked less than 5 years, respondents with length of work 6-10 years were 53 people $(82.8 \%)$, length of work 11-15 years were 5 people $(7.8 \%)$, length of work $16-20$ years 1 person (1.6\%) and more than 26 years of work as many as 5 people $(7.8 \%)$. Judging from the level of education, respondents consisted of 2 high school graduates (3.1\%), 20 diploma graduates $(31.3 \%), 37$ undergraduate graduates $(57.8 \%)$, and 5 master / doctoral graduates $(7,8 \%)$.

Research respondents consisted of several positions and work unit functions at PT. Pertamina Drilling Services Indonesia. Based on the position, 6 respondents held the position of vice president $(9.4 \%), 6$ respondents were managers $(9.4 \%), 10$ respondents were assistant managers $(15.6 \%)$, and 42 respondents were staff $(65.6 \%)$. The results of the description of respondents based on work functions, respondents came from 9 different work functions. Validity test is done by conducting a bivariate correlation between each indicator score with the total construct score. Based on the results of the validity test attached, all questionnaire questions related to leadership variables (X1), performance evaluation system variables (X2), motivation variables (X3), job satisfaction variables (Y1), and employee performance variables (Y2) it appears that the correlation between each indicator to the total construct score showed significant results. So, it can be concluded that each question indicator is valid.

Based on Reliability Test Results Table, it is known that the Cronbach Alpha values of all variables have values above 0.70 , it can be concluded that all the variables in this study passed the reliability test and were declared reliable. Multicollinearity test aims to test whether in the regression model there is a correlation between independent variables. A good regression model should not occur correlation between independent variables. Multicollinearity detection by looking at tolerance and variance inflation factor (VIF). The commonly used value is the tolerance value of 0.10 or equal to the VIF value above 10 . The tolerance level of 0.10 indicates that there has been a multicollinearity problem of 0.95 according to Ghozali [23].

Based on Multicollinearity Test Results, there are no variables with tolerance values below 0.10 and VIF above 10 so that it can be interpreted that all the independent variables in the study did not correlate with each other. Refer to the graph Normality Test Results, it is known that all data in the study are normally distributed, because all data spread in a diagonal straight line then the data meets the assumption of normality. In addition to looking at the graph, the normality of the data is also measured using the Kolmogorov-Smirnov test at alpha of 5\%. Normality Test Results, shown that the p-value of 0.36 is greater than 0.05 so it can be concluded that the data are normally distributed. 
Based on the scatterplots graph, it is seen that the points spread randomly and are spread between the $\mathrm{X}$ and $\mathrm{Y}$ axes. This shows that there is no heteroscedasticity problem in the research data. To strengthen that there has been a heteroscedasticity problem in the research data. Glesjer test was performed to provide more detailed figures to confirm whether the data to be processed is heteroscedasticity disturbed or not. The presence or absence of heteroscedasticity disorders can be seen from the significance value of the independent variable on the dependent variable. If the results of the Glesjer test are less than or equal to 0.05 , it can be concluded that the data have heteroscedasticity disorders and vice versa according to Ghozali [23].

Refer to results of the Glesjer test, all research variables have significance above $5 \%$ so that it is known that all the research variables do not occur heteroscedasticity problems. Based on the regression results, the constant shows a positive value of 1.164 , meaning that if leadership, work evaluation systems and motivation work together with zero, then job satisfaction is positive. The value of the regression coefficient for the leadership variable (X1) of 0.339 is also positive, meaning that increasing leadership will increase worker satisfaction with the assumption that the employee's assessment system variable and work motivation are considered constant. Next the regression coefficient value for the variable performance appraisal system (X2) is negative at 0.085 , meaning that every 1-point increase in the performance appraisal system variable will result in lower employee satisfaction of 0.085 if the leadership and work motivation variables are considered constant. The regression coefficient of the variable of work motivation (X3) is positive 0,460 . This means that the employee's work motivation increases, the perceived job satisfaction also increases with the assumption that other research variables are considered constant or constant.

The model accuracy test results are known from the F value with p-value (sig.) 0,000 $<0.05$ so that the model is right to predict the effect of leadership, work evaluation system and work motivation on employee satisfaction. The coefficient of determination (R2) shows a value of 0.594 , which means that the leadership variable, the employee assessment system, and work motivation explain $59.4 \%$ of worker satisfaction, while the remaining $40.6 \%$ is explained by other factors outside the research variable such as the work environment, competence, and organizational culture.

Based on the regression results, the constant shows a positive value of 0.285 , meaning that if leadership, work evaluation systems, work motivation, and employee satisfaction are zero, then employee satisfaction is positive. The value of the regression coefficient for the leadership variable (X1) is 0.444 positive, meaning that increasing leadership will improve employee performance with the assumption that the employee rating system variables, work motivation and employee satisfaction are considered constant. The value of the regression coefficient for the employee rating system variable (X2) of 0.080 is also positive, meaning that a better employee rating system will improve employee performance assuming leadership, work motivation and employee satisfaction variables are considered constant.

The regression coefficient for the employee satisfaction variable is also positive at 0.569 , which means that every 1-point increase in the employee satisfaction variable will increase employee performance by 0.569 points if the leadership variable, employee rating system, and work motivation are considered constant. Inversely proportional to the regression coefficient for work motivation variable (X3) which has a negative value of -0.133 , meaning that every 1-point increase in work motivation variable will actually cause employee performance to decrease by 0.133 points with the assumption of other independent variables in constant research. 
The model accuracy test results are known from the F value with p-value (sig.) 0,000 $<0.05$ so that the model is right to predict the effect of leadership, work evaluation system, work motivation, and employee satisfaction on employee performance. The coefficient of determination (R2) shows a value of 0.729 which means that the leadership variable, the employee assessment system, work motivation and employee satisfaction explain $72.9 \%$ of employee performance, while the remaining $27.1 \%$ is explained by other factors outside the research variable such as competence, organizational culture and employee incentives.

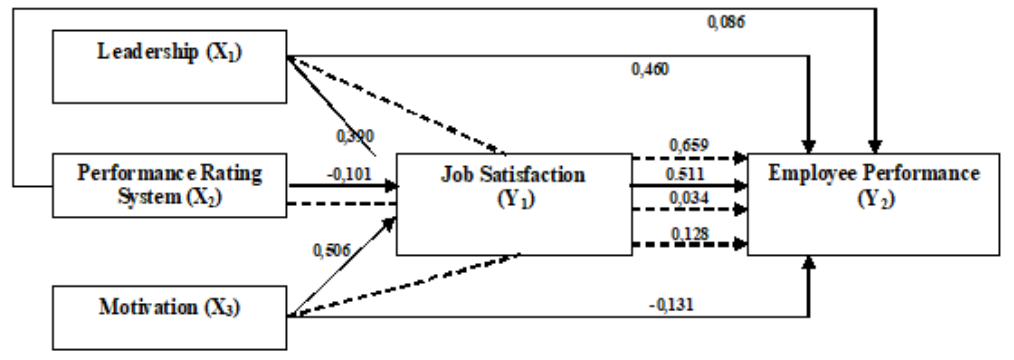

Based on the calculation of direct and indirect effects, it is found that the direct influence of leadership on employee performance variables is 0.460 greater than the indirect effect of 0.199. This shows that leadership style can improve employee performance better even though it is not supported by employee satisfaction. Similarly, the work evaluation system variable which has a direct influence of 0.086 is greater than the indirect effect of -0.052 . This shows that the performance appraisal system can improve employee performance even though employee satisfaction is not achieved. This is inversely proportional to two other independent variables namely work motivation which has an indirect effect of 0.259 higher than the direct effect -0.131 on employee performance variables. With the motivation to work better, employees will get better job satisfaction and produce better performance.

\subsection{Research Result}

Based on the regression test results above, it is known that leadership has a $t$ count of 2.802 with a p-value of $0.007<0.05$ which means that the leadership variable has a significant effect on employee job satisfaction. Regression test results show the $t$ value for the performance appraisal system variable is negative 0.776 with a p-value of $0.441>0.05$ which means that the performance appraisal system has no effect on employee job satisfaction. Regression test results show the $t$ value of 3.487 with a p-value of $0.001>0.05$, meaning that work motivation has a significant effect on employee job satisfaction. The higher the employee motivation to work, the job satisfaction obtained by employees will also be higher.

Based on the results of the regression test above, it is known that leadership has a $t$ count of 3.764 with a p-value of $0,000<0.05$ which means that the leadership variable has a significant effect on employee performance. The better the leadership style, the better the performance of employees in the organization. Regression test results show the $t$ value of 0.795 with a p-value of $0.430>0.05$, meaning that the performance appraisal system has no effect on employee performance. The better the employee performance appraisal system actually results in worse employee performance. Regression test results show the t value for the performance appraisal system variable is negative 0.998 with a p-value of $0.322>0.05$ which means that work motivation has no effect on employee performance. 
Regression test results show the $t$ value for the variable job satisfaction of 4.798 with a p-value of $0.000<0.05$ which means that job satisfaction has a significant effect on employee performance. The higher job satisfaction achieved by employees, the better the performance will be. Job satisfaction variables are not able to mediate the relationship between leadership variables and employee performance. Based on path analysis and the test of influence both directly and indirectly, it is known that the variable job satisfaction is not able to mediate the relationship between the variable work evaluation system with employee performance. Employee job satisfaction variables can improve the relationship between motivation variables and employee performance variables. In line 1 it is known that motivation can increase employee job satisfaction which results in improved performance.

\subsection{Discussion of Research Results}

\subsubsection{The Influence of Leadership on Employee Job Satisfaction}

Based on the results of the regression test above, it is known that leadership has a $t$ count of 2.802 with a p-value of $0.007<0.05$, which means that the leadership variable affects employee job satisfaction. This shows that the better the leadership style in an organization, the better the level of employee job satisfaction. The results of this study support the research of Jong \& Hartog [24], and Yukl [25] which show that leadership styles can increase employee job satisfaction. The Effect of the Performance Appraisal System on Employee Job Satisfaction. The regression test results show that the $t$ value for the performance appraisal system variable is negative 0.776 with a p-value of $0.441>0.05$, which means that the performance appraisal system has no effect on employee job satisfaction. The results of this study reject the research of Khan [26] and Karimi et al. [27] which states that there is a positive correlation between the performance appraisal system and the level of job satisfaction.

However, the research results support Dangelico, Rosa MariaVocalelli, Daniele [28] research which states that employees are not satisfied with the performance appraisal system adopted by their organization. This is a good input for the organization in order to develop a better and more objective performance appraisal system in order to increase job satisfaction. Schneider et al. [29] stated that employee satisfaction is the key to better individual and / or organizational performance.

\subsubsection{Effect of Motivation on Employee Job Satisfaction}

The results of the regression test show the $t$ value of 3.487 with a p-value of $0.001>0.05$, meaning that work motivation has an effect on employee job satisfaction. The higher the employee's work motivation, the higher the job satisfaction the employee will get. The results of the study support previous research conducted by Herzberg et al.[5], [30], Baah and Amoako [30], Hasibuan [10], and Raziq \& Maulabakhsh [11] which state that work motivation can increase employee job satisfaction. Motivation to work will encourage employees to work hard by giving all their energy and abilities to realize organizational goals. Then the higher the motivation to work, the employee's performance will be better. In addition, Baah and Amoako [30] also explain that the level of employee motivation will ultimately increase employee happiness and is a driving force in achieving job satisfaction.

\subsubsection{The Influence of Leadership on Employee Performance}

Based on the results of the regression test above, it is known that leadership has a $t$ count of 3.764 with a p-value of $0.000<0.05$, which means that the leadership variable affects employee performance. The better the leadership style, the better the employee's 
performance in the organization. This is in line with previous research conducted by Hasibuan [10] which states that leadership will encourage employees to work effectively and efficiently to achieve organizational goals. With a good leadership style, leaders can direct their employees to have better quality work.

\subsubsection{The Effect of the Performance Appraisal System on Employee Performance}

The regression test results show the $t$ value of 0.795 with a $p$-value of $0.430>0.05$, meaning that the performance appraisal system has no effect on employee performance. The better the employee performance appraisal system, the worse the employee performance. The results of this study reject previous research conducted by Dhewi et al. [31]; Hidayat [21]; Mukti et al. [32] which shows that performance appraisal is a factor that affects job satisfaction. However, the research results support Dangelico, Rosa MariaVocalelli, Daniele [28] research which states that employees are not satisfied with the performance appraisal system adopted by their organization. This is a good input for the organization so that it can develop a better and more objective performance appraisal system in order to improve employee performance to achieve organizational goals.

\subsubsection{Effect of Motivation on Employee Performance}

The regression test results show that the $\mathrm{t}$ value for the performance appraisal system variable is negative 0.998 with a p-value of $0.322>0.05$, which means that work motivation has no effect on employee performance. Raziq \& Maulabakhsh [11] which state that work motivation can encourage employees to carry out their activities and encourage maximum employee performance. The results of this study support the research (Katiandago, Mandey, S, \& Mananeke,) [33] which states that motivation has no effect on employee performance. Katiandago et al. [33] states that motivation is closely related to the attitudes and behavior of a person. The attitudes that exist in each individual interact with emotions, values, roles, environment, and social structure. Each individual has a different environmental and social background so that motivation that appears in each individual will be different. So, motivation cannot determine the quality of employee performance.

\subsubsection{Effect of Job Satisfaction on Employee Performance}

The results of the regression test showed that the $t$ value for the job satisfaction variable was 4.798 with a p-value of $0.000<0.05$, which means that job satisfaction has an effect on employee performance. The higher the job satisfaction achieved by the employee, the better the performance will be. The results of this study support previous research conducted by Lund [34] which states that employee performance is strongly influenced by job satisfaction. Lund [34] in his research shows that job satisfaction described in salary satisfaction, promotion, supervision and cooperation between employees has a huge influence in improving performance. It is important for organizations to create job satisfaction for their employees so that better performance can be created and ultimately assist the organization in achieving its goals.

\subsubsection{The Influence of Leadership on Employee Performance through Job Satisfaction as an Intervening Variable}

Based on the path analysis and influence test, both direct and indirect, it is known that job satisfaction is not able to mediate the relationship between leadership variables and employee performance. This does not support the research results of Mukmin, Budiarto \& Prasetyo [35], which state that job satisfaction is an intervening variable in explaining the 
relationship between leadership and employee performance. This may occur because job satisfaction is not the main cause of the influence of leadership on performance, which means that regardless of whether employees are satisfied, leadership will still directly affect employee performance. Therefore, company leaders need to be objective and focus on leadership patterns that can improve employee performance, not solely on performance satisfaction.

\subsubsection{The Effect of the Performance Appraisal System on Employee Performance through Job Satisfaction as an Intervening Variable}

Based on the path analysis and impact test, both direct and indirect, it is known that job satisfaction is not able to mediate the relationship between job appraisal system variables and employee performance. This does not support the results of the research by Mukti et al [32] which states that performance appraisal through e-performance affects employee performance through job satisfaction, meaning that in the scope of research at PDSI, employee performance variables are better to become independent variables. This happens in companies that job satisfaction is not a consideration for someone to improve performance, the existence of a performance appraisal system regardless of whether or not satisfied will be able to improve employee performance. Therefore, the preparation of an objective and precise performance appraisal system will be better able to improve employee performance without considering the system's satisfaction.

\subsubsection{The Influence of Motivation on Employee Performance through Job Satisfaction as an Intervening Variable}

Based on the path analysis and impact test, both direct and indirect, it is known that the employee job satisfaction variable can improve the relationship between the motivation variable and the employee performance variable. In path 1 it is known that motivation can increase employee job satisfaction which leads to increased performance. This supports the results of the research of Wijaya et al [36] which states that work motivation has a significant effect on job satisfaction and has a positive effect on employee performance. In addition, Azzuhri's [19] research results show that work motivation indirectly has a significant effect on employee performance through job satisfaction. This shows that the importance of motivation is able to influence satisfaction which in turn will have an impact on employee performance. Therefore, companies should provide motivation that has an impact on performance satisfaction which in turn will be able to improve employee performance in a wise manner

\section{Conclusion}

The results of the study showed that there was a significant influence of Leadership and Motivation variables on employee job satisfaction while the Performance Evaluation System variable did not affect employee job satisfaction. Furthermore, for the variable of leadership has a significant influence on employee performance, while the Performance Appraisal System and Motivation has no effect on employee performance. Job satisfaction has a significant effect on employee performance. The better job satisfaction obtained by employees; the employee's performance will also improve. Job satisfaction mediates the relationship between work motivation and employee performance. 


\section{References}

[1] J. L.Gibson, J. M. Ivancevich, J. H. D. Jr., and R. Konopaske, Organizations Behavior, Structure, Processes, Fourteenth Edition. 2017.

[2] L. M. Keeping and P. E. Levy, "Performance appraisal reactions: Measurement, modeling, and method bias," J. Appl. Psychol., 2000, doi: 10.1037/0021-9010.85.5.708.

[3] D. Langford, R. F. Fellows, M. R. Hancock, and A. W. Gale, "Organizational behaviour," in Human Resources Management in Construction, 2020.

[4] H. J. Whiting, T. J. B. Kline, and L. M. Sulsky, "The performance appraisal congruency scale: An assessment of person-environment fit," Int. J. Product. Perform. Manag., 2008, doi: 10.1108/17410400810857239.

[5] C.-R. Giroux, "The Motivation to work, by F. Herzberg, B. Mausner and B.-C. Snyderman, John Wiley \& Sons, New York, John Wiley \& Sons, 1959.," Relations Ind., 2017, doi: 10.7202/1022040ar.

[6] S. P. Robbins, T. A. Judge, A. Odendaal, and G. Roodt, Organisational behaviour: Global and Southern African Perspectives. 2016.

[7] R. Kreitner and A. Kinicki, "Perilaku Organisasi Organizational Behavior," in 1, 2014.

[8] S. P. Robbins and T. A. Judge, Organizational Behavior 15th Edition. 2013.

[9] R. L. Mathis and J. H. Jackson, "Manajemen Sumber Daya Manusia," in Manajemen Sumber Daya Manusia, 2012.

[10] M. S. P. Hasibuan, "Manajemen Sumber Daya Manusia," Ed. Revisi Jakarta Bumi Aksara, 2011.

[11] A. Raziq and R. Maulabakhsh, "Impact of Working Environment on Job Satisfaction," Procedia Econ. Financ., 2015, doi: 10.1016/s2212-5671(15)00524-9.

[12] A. B. Saluy and Y. Treshia, "Pengaruh Motivasi Kerja, Disiplin Kerja dan Kompensasi Terhadap Kinerja Karyawan (Studi Kasus di Perusahaan PT IE)," J. Univ. Mercu Buana, 2018.

[13] D. Zaenudin and M. Djamil, "Pengaruh Kompensasi, Motivasi dan Lingkungan Kerja Terhadap Kinerja Karyawan PT. AEM,” J. Ilm. Manaj. Bisnis, 2016.

[14] V. H. Vroom and A. G. Jaago, "The role of the situation in leadership," Am. Psychol., 2007, doi: 10.1037/0003-066X.62.1.17.

[15] T. A. Judge, C. L. Hulin, and R. S. Dalal, "Job Satisfaction and Job Affect," in The Oxford Handbook of Organizational Psychology, 2012.

[16] F. Luthans, Perilaku Organisasi, Edisi Sepuluh. 2006.

[17] B. Rusli, "Kebijakan Publik: Membangun Pelayanan Publik yang Responsif," Kebijak. Publik, 2013.

[18] Y. Hanifah, "Hanifah,Yusnia,” J. Bisnis dan Manaj., 2017.

[19] N. Fauzi, Ahsan, and M. Azzuhri, "Pengaruh Faktor Individu, Organisasi dan Perilaku terhadap Kepatuhan Perawat dalam Melaksanakan Hand Hygiene di Ruang Rawat Inap Rumah Sakit Tk. II Dr. Soepraoen Malang,” J. Apl. Manaj., 2015.

[20] "Characteristics of Appraisal Systems That Promote Job Satisfaction of Teachers.," Educ. Res. Perspect., 2014.

[21] R. Hidayat, "Performance Appraisal sebagai Alat Pengukuran Kepuasan Kerja Karayawan," Ilman, 2015.

[22] F. Nawa and S. Kempa, "Pengaruh Kompensasi Dan Disiplin Kerja Terhadap Kinerja Karyawan Pada Pt . Pln ( Persero ) Wilayah Nusa Tenggara Timur,” AGORA Vol. 5, No 3, 2017.

[23] I. Ghozali, "Aplikasi Analisis Multivariate dengan Program IBM SPSS. Yogyakarta: Universitas Diponegoro,” (Edisi 9). Semarang Badan Penerbit Univ. Diponegoro, 2018.

[24] J. De Jong and D. Den Hartog, Leadership as a Determinant of Innovative Behaviour: A Conceptual Framework. 2003.

[25] G. Yukl, Leadership in Organisations 7th ed. 2010. 
[26] A. Khan, "Performance Appraisal's Relation with Productivity and Job Satisfaction," J. Manag. Sci., 2010.

[27] R. Karimi, M. I. Malik, and S. Hussain, "Examining The Relationship Of Performance Appraisal System And Employee Satisfaction,” Int. J. Bus. Soc. Sci., 2011.

[28] R. M. Dangelico and D. Vocalelli, “'Green Marketing': An analysis of definitions, strategy steps, and tools through a systematic review of the literature," Journal of Cleaner Production. 2017, doi: 10.1016/j.jclepro.2017.07.184.

[29] B. Schneider, P. J. Hanges, D. B. Smith, and A. N. Salvaggio, "Which Comes First: Employee Attitudes or Organizational Financial and Market Performance?," J. Appl. Psychol., 2003, doi: 10.1037/0021-9010.88.5.836.

[30] D.-B. Kwasi and A. George, "Application of Frederick Herzberg's Two-Factor theory in assessing and understanding employee motivation at work: a Ghanaian Perspective Kwasi," Phys. Chem. Chem. Phys., 2000.

[31] “ANALISIS PENGARUH EFEKTIVITAS SISTEM PENILAIAN KINERJA TERHADAP MOTIVASI KERJA, KEPUASAN KERJA DAN KINERJA KARYAWAN PT COATS REJO INDONESIA," J. Manaj. Agribisnis, 2011, doi: 10.17358/jma.3.1.1-17.

[32] D. R. Mukti, S. W. Lelly Hana Setyanti, and L. Farida, "Penerapan Sistem Penilaian Kinerja Berbasis E-Kinerja Terhadap Prestasi Kerja Pegawai Melalui Kepuasan Kerja Sebagai Variabel Intervening Pada Dinas Kependudukan dan Pencatatan Sipil Kabupaten Banyuwangi," e-Journal Ekon. Bisnis dan Akunt., 2019, doi: 10.19184/ejeba.v6i2.11166.

[33] L. Mananeke, S. Mandey, and C. Katiandagho, "PENGARUH DISIPLIN KERJA KEPEMIMPINAN DAN MOTIVASI TERHADAP KINERJA PEGAWAI PADA PT. PLN (PERSERO) WILAYAH SULUTTENGGO AREA MANADO,” J. Ris. Ekon. Manajemen, Bisnis dan Akunt., 2014, doi: 10.35794/emba.v2i3.5919.

[34] D. B. Lund, "Organizational culture and job satisfaction," J. Bus. Ind. Mark., 2003, doi: 10.1108/0885862031047313.

[35] S. Mukmin, W. Budiarto, and I. Prasetyo, "Pengaruh Gaya Kepemimpinan dan Budaya Organisasi Terhadap Kinerja Karyawan Melalui Kepuasan Kerja Karyawan Sebagai Variabel Interveing,” J. Manaj. dan Adm. Publik, 2015.

[36] W. G. Wijaya, I. K. S. Sapta, A. A. Putu Agung, and I. N. Sudja, "Leadership Effect and Work Motivation to Employee's Performance with Work Satisfaction as a Mediation Variable (Study in the Denpasar City Regional Agency)," Int. J. Contemp. Res. Rev., 2019, doi: 10.15520/ijcrr.v10i02.667. 